\title{
Manufacturing Chiefly Consent? James Busby and the Role of Rangatira in the Pre-Colonial Era'
}

\section{VINCENT O'MALLEY}

The story of James Busby's role as official British Resident in New Zealand between 1833 and the signing of the Treaty of Waitangi in 1840 has been told many times. This paper focuses on one aspect of Busby's performance of those duties which has received comparatively little attention. From the outset the British Resident set about creating a centralized body of chiefs through which he hoped to indirectly govern the tribes. These efforts ran contrary to customary Maori decision-making processes which involved a much wider group than rangatira. Though far from a resounding success, to a large extent Busby's efforts to elevate the authority of rangatira for ulterior ends set the platform for similar Crown policies pursued after 1840. While there were many factors impacting upon the standing of rangatira in the pre-Waitangi era, this paper suggests that Busby's attempts to manipulate customary relations in this manner warrant closer attention.

It was at one time popularly assumed that the series of tribal conflicts waged after 1818 and known today as the 'musket wars' constituted an entirely new type of warfare in Maori society. Inspired by European ideas, so the argument went, the Ngapuhi rangatira Hongi Hika set out to establish himself as a Napoleon or King George of New Zealand, holding sway over a newly-united nation under his own personal leadership. ${ }^{2}$ Such an argument ignored several basic facts concerning the course of these wars, including the obvious point that the northern taua rarely took any steps to occupy or permanently retain any of the lands they took control of - surely the first step in any campaign aimed at establishing one's dominion. It was also based on some entirely erroneous conceptions as to the nature of leadership and the role of rangatira in Maori society. Although there were some exceptions to this, many early European observers perceived Maori society in hierarchical terms - much like the highly class-bound communities from which they themselves had come - and viewed the authority of the chiefs as absolute. ${ }^{3}$

John Savage, who after visiting the north of New Zealand in 1805 authored the first work focused solely on the country, described the form of government he observed at the Bay of Islands to be 'aristocratical, and 
hereditary'. ${ }^{4}$ John Nicholas similarly concluded in his 1817 account of a visit to the islands that ' $[\mathrm{t}] \mathrm{he}$ power of the chiefs . . . is in general absolute', though he added that 'in some districts it is restrained by certain limitations, and controuled [sic] in a great measure by public opinion. ${ }^{5}$ This qualification was more general than Nicholas appreciated. At least some early European observers came close to appreciating the point. Richard Cruise, who visited New Zealand just a few years later, noted that whilst at Hauraki he had encountered 'a person bearing the title of areekee... who was said to exert a very despotic control over many of the neighbouring chiefs' but that 'in the intercourse he maintained with his countrymen, no more respect or distinction was paid to him than to any other chief.' ${ }^{6}$ The missionary Samuel Marsden noted during his first visit to New Zealand in 1814 that 'there appears to be no middle class of people in New Zealand . . . they are all either chiefs or, in a certain degree, slaves. At the same time, the chiefs do not give their commands to the people indiscriminately as a body with that authority which masters, in civil life, exercise over their servants, nor do their dependents feel themselves bound to obey such commands. ${ }^{7}$

Frederick Maning, the author of the classic work Old New Zealand, observed that 'the natives are so self-possessed, opinionated, and republican, that the chiefs have at ordinary times but little control over them, except in very rare cases, where the chief happens to possess a singular vigour of character, or some other unusual advantage, to enable him to keep them under. ${ }^{8}$ Later observers agreed with these assessments. According to Francis Dart Fenton, writing in 1857:

No system of government that the world ever saw can be more democratic than that of the Maoris. The chief alone has no power. The whole tribe deliberate on every subject, not only politically on such as are of public interest, but even judicially they hold their "komitis" on every private quarrel. In ordinary times the vox populi determines every matter, both internal and external. The system is a pure pantocracy, and no individual enjoys influence or exercises power, unless it originates with the mass and is expressly or tacitly conferred by them. ${ }^{9}$

Although Fenton and other commentators suggested that rangatira could be accorded large powers during times of war, this applied no more widely than to their own hapu. George Clarke, a member of the Church Missionary Society, concluded that 'a New Zealander in the field of battle is the most ungovernable creature immaginable [sic] for though a Soldier he is quite independent and if he likes he will obey the voice of his leader or he will not ${ }^{10}$ To the extent that Hongi Hika led any taua, or war party, it was largely a matter of persuasion, reputation, force of personality, and by personal example, rather than in accordance with any recognized authority. The rangatira himself informed Marsden that whilst at war "he was feared and 
respected, but when he was at home they would not hearken to anything he might say'. ${ }^{11}$ Henry Williams, in response to a query as to why one war party had not kept a closer formation, was informed that it was their usual way for each party to go where they liked, that every one was his own chief. Without any one to direct, not only does each tribe act distinct from the other, but each individual has the same liberty. If one be bent on mischief, he cannot be restrained by the others. ${ }^{12}$

Rangatira, in short, had great influence over their hapu, but little actual authority beyond that conferred on them by the wider community to implement the will of the group. As Angela Ballara notes, decision-making was 'a matter of discussion, compromise, and consensus ... [ [which] almost always - save in the case of slaves or client hapu - called for the voluntary assent of the persuaded rather than obedience to any authority'. ${ }^{13}$ If there was an incentive to take the word of the chief seriously it lay in the fact that the rangatira was considered the personal embodiment of the mana of the hapu. His misfortunes and reversals would be shared by the wider community and this often created a good reason for both chiefs and their communities to co-operate. ${ }^{14}$

The question, then, is whether the role, status and authority of rangatira was enhanced or diminished in the post-contact era. Many early observers, assuming that the authority of the chiefs had earlier been more or less absolute, could not fail to conclude that this had subsequently suffered a serious and almost crippling decline. But if a more realistic starting point is adopted then the consequences of early European contact on chieftainship appear more mixed.

In some respects the new environment necessarily strengthened the hand of the rangatira. The largely self-regulating pre-contact world created little scope for chiefly intervention on a regular basis. ${ }^{15}$ This could not be said for the early decades of the nineteenth century. One of the areas in which rangatira had always had an acknowledged role, for example, was in distributing the commonly-held resources of the community. In the early contact era the range and sheer quantity of such resources increased significantly and the chief often assumed an important role as entrepreneur and intermediary between his people and European traders. Although not always the case, payments for work undertaken by hapu members might, for example, be made solely to the rangatira, who would then be responsible for distributing these more widely, reinforcing his customary role as a focal point for the accumulation and distribution of tribal wealth. ${ }^{16}$

The introduction of Christianity, and its impact on chieftainship, also requires consideration. Many historians have argued that chiefs proved the most resistant members of their communities to the new religion, fearing its impact on their own mana, tapu and social standing, though this assertion 
has been questioned by others. ${ }^{17}$ There is, it has to be said, considerable anecdotal evidence in support of the former case. ${ }^{18}$ It seems beyond doubt that many rangatira did deplore the levelling consequences of Christianity upon their own mana and remained resistant to the new faith. But there were undoubtedly also some rangatira who saw opportunities as well as threats in the new religion, including tohunga who perceived the chance to enhance their own standing by harnessing the energies of the new faith, in much the same way that they had been acknowledged as experts in the existing cultural practices. ${ }^{19}$

Perhaps the most accurate overall assessment as to the impact of the pre-colonial era on the authority of the chiefs would be to say that it was mixed. If some rangatira saw religious change as a threat to their social status, others perceived that the new environment offered opportunities to enhance their mana through trade or other means. Many Europeans found it more convenient to work through chiefs rather than negotiating with large hapu over all manner of issues, further enhancing the ability of rangatira to control matters. It is this political dimension, for want of a better description, that is the focus of the remainder of this paper.

The appointment of James Busby as British Resident for New Zealand in 1832 came in response to a letter sent by a number of Northland rangatira to the British monarch a year earlier. These developments marked the intensification of a relationship between northern Maori especially and the British Crown which was first established in earnest with Governor Philip King's various dealings with the Northland tribes from the 1790s onwards. ${ }^{20}$ The background to Busby's appointment and the successes and failures of his efforts in New Zealand have been discussed at length elsewhere, ${ }^{21}$ but Busby's role as an agent of socio-cultural and political change among the northern tribes is less well-known. Yet almost from the time of his arrival in New Zealand Busby set about challenging existing leadership and governance structures among northern Maori in his efforts to manufacture a more centralized form of government, open to his ready manipulation on behalf of the British Crown.

Busby, soon after landing at the Bay of Islands in May 1833, responded to the earlier 1831 petition of the northern chiefs, which asked King William for protection. ${ }^{22}$ The response, read to a gathering of some 22 rangatira assembled at Paihia mission station on 17 May 1833, explained that Busby had been sent to them as a 'kaiwhakarite', or intermediary between the two peoples. By the appointment of Busby, it was declared, the King was increasing the chiefly authority of the rangatira of New Zealand. ${ }^{23}$ But as James Busby later explained to his brother Alexander, his aim in establishing close working relationships with the chiefs was to give him 'almost entire authority over the Northern part of the Island'. ${ }^{24}$ A kind of indirect rule 
through the rangatira remained his objective throughout the early part of his residency. In various guises it might also be said to have been the prevailing objective of Crown officials for at least the next three decades. ${ }^{25}$

This approach was entirely consistent with the instructions issued to Busby, which had required him to exert his influence over the chiefs at an early date in order to bring about a more settled state of affairs. ${ }^{26}$ Given the unwillingness to provide the British Resident with military backing, this was about the best Busby could hope to achieve. Yet Busby soon learnt that any notions he may have garnered from early published works on New Zealand describing a relatively hierarchical social structure not that dissimilar from the English one were erroneous. He had brought with him presents of clothing for 15 rangatira to be distributed following the initial hui, only to be informed by the missionaries that there were no less than 40 persons of equal standing to whom it would be necessary to make such gifts in order to avoid giving offence to any of them. While Busby hastily made arrangements to borrow a few pairs of blankets from the missionaries in order to make alternative presents to the rangatira, he further learnt that it would be necessary to lay on a feast for the entire body of assembled Maori, numbering some 500 to 600 people in total. ${ }^{27}$

Busby quickly concluded that the existing authority of rangatira was insufficient to allow meaningful governance on any feasible scale. He noted that chiefly jealousies would conspire against any proposals towards a confederated form of government in the short-term, although he took steps to overcome such division by insisting on dealing with the chiefs in a 'collective capacity only'. ${ }^{28}$ Not only this, but as the Resident further reported in 1834, Maori and British notions of justice were so completely contrary that he could 'hold out but little hope of being able to maintain order through the power of the native Chiefs'. ${ }^{29}$

It must, at first, have seemed to Busby like a minor triumph when in January 1836 two tribes contending ownership of lands at Whananaki agreed to take their claims before the British Resident for mediation. But as fierce debate raged between the parties assembled in front of Busby's house, one of the groups opened fire on the other. Busby later reported that the floor of his house was soon 'covered with blood of the wounded men', whilst by some accounts at least two people were killed in the attack. ${ }^{30}$ Having at length and with great difficulty eventually succeeded in preventing a 'general massacre', Busby was left to deal with the aftermath of the incident, which he firmly believed had been premeditated.

The incident produced at least some encouraging news for Busby. The injured party informed the British Resident that 'they had given up their native practices, and would leave with me the reproach of their Countrymen'. ${ }^{31}$ But Busby soon discovered 'a disposition to pass the matter 
over very lightly; if not to justify it according to native usages'. ${ }^{32}$ He might have considered the whole incident an affront to the King of England which demanded a vigorous response, but perhaps the most surprising thing about this whole incident was the participants' failure to seek utu for those slain - an omission evidently felt keenly by some of the relatives of the killed and wounded. ${ }^{33}$

The complexity of the situation confronting Busby is illustrated by an earlier incident in which he experienced the Maori justice system at close range. In April 1834 a group of Maori broke in to his storehouse at Waitangi, firing muskets at him and causing a minor wound in consequence of a splinter striking him in the cheek. One of the parties initially accused was suspected of taking utu from Busby for the desecration of an urupa by a Maori resident at Waitangi; others accused of the attack had threatened to seek payment for the false allegations levelled against them; and meanwhile, when suspicion for a time fell upon hapu from the Okiato area, it was proposed to gain utu by attacking the stores of local settlers. ${ }^{34}$

Finally, in October 1834, nearly six months after the original attack, the true culprit was unearthed, and eventually confessed to having fired the shot at Busby. While Busby somewhat ludicrously insisted that Reti, a local rangatira, and two of his slaves who had also joined in the attack, should be executed, the missionaries instead proposed a compromise punishment involving the confiscation of the chief's land and his banishment from that part of the island. ${ }^{35}$

A small group of rangatira assembled to determine Reti's fate and somewhat reluctantly confirmed the proposals for the confiscation of a few hundred acres of land followed by Reti's exile. HMS Alligator had reached the Bay of Islands just days earlier, fresh from its bloody assault on Taranaki Maori in retaliation for the Harriet affair, ${ }^{36}$ and Henry Williams for one seemed to believe that its presence had been the decisive factor in securing consent to the confiscation. ${ }^{37}$ Reti now denied any involvement in the original crime, however, and declared his intention to ignore any order to leave. ${ }^{38}$ Meanwhile, the remaining rangatira proved reluctant to take any actions to enforce their earlier determination..$^{39}$ The problem, as Busby had correctly predicted, was that they were incapable of taking any action in the matter without personally incriminating themselves in a move which would demand utu from the offended party. ${ }^{40}$ Quite how, under these circumstances, Busby had imagined anyone being found who could execute the accused chief without fear of serious repercussions defies imagination.

In various ways, then, Busby had endeavoured to get the northern rangatira to act in concert in matters he deemed important. And although his record on this front was mixed, he did achieve two notable successes with the selection of a national flag in March 1834, and the signing of He Wakaputanga o te 
Rangatiratanga o Nu Tirene (the Declaration of Independence) in October $1835 .{ }^{41}$ But at the same time that Busby was encouraging rangatira to work together to establish supra-tribal institutions of authority capable of administering the affairs of the country under the protection of the British, he was also working at another level to elevate the authority of the higherranked chiefs.

Following the initial signing of He Wakaputanga, for example, Busby commented that the Declaration settled the basis of government for the country on the principle he had always recommended, namely 'that the powers of a Government should be vested exclusively in the Chiefs of Tribes, in their Collective capacity'. This, Busby asserted, 'I conceived to be the form of Government which naturally strings from the actual condition of the people'. ${ }^{42}$ The viewpoint expressed on this occasion was not exactly in accordance with his later statements on the same subject. Writing in response to Sir William Martin's attack on the government's handling of affairs at Taranaki in 1860 , Busby noted with respect to the pre-1840 period that:

In New Zealand, law had no existence, and there was an equal absence of authority. No man admitted the right of another to interfere with his conduct. We are accustomed to speak of the "chiefs" of New Zealand, in terms which to our minds convey the idea of authority. But the chiefs had no authority. Those were "principal chiefs" who, being free men, had acquired that ascendancy which, superior natural ability and strength of mind always obtain over the less gifted and more timid majority, as well as those who stood nearest in lineal descent to the original progenitor from whom they all traced their descent. But, however naturally gifted, or lineally descended, no man claimed a right to subject another to his will. ${ }^{43}$

Yet Busby's 1860 depiction of an anarchic, free-for-all society in which might invariably triumphed over right was no more accurate than his earlier, neat and convenient conception of a government of the (principal) chiefs. ${ }^{44}$ In reality, decision-making processes were collective, and although there was no overall authority governing relations between tribes, mechanisms such as taua muru (plundering or punishment raids) and runanga (tribal councils) existed to mediate disputes between neighbouring communities. ${ }^{45}$

Busby's efforts in the 1830 s to establish a confederated government of the chiefs ran counter to this collective decision-making ethos in that it made no effort to ensure the participation of the lesser rangatira. William Barrett Marshall, who was present at the hui during which a national flag was selected, observed that 'the spectacle might have been rendered an imposing one, but for the attempt made to separate between the noblesse and the canaille of New Zealand, by confining the choice of the flag to the former, and excluding altogether the voice of the latter from taking 
part in the affair. ${ }^{46}$ Marshall noted that this move had prompted 'no small discontent' on the part of those excluded. He was critical of Busby's efforts to stifle free and open debate on the issue, and observed that at the end of the meeting, while some adjourned to a feast, others assembled 'without respect of persons, to listen to the disputes brought forward by individuals, according to the immemorial custom of every public assembly'. ${ }^{47}$ Busby himself had warned those assembled for the occasion that although they were free to choose whichever flag they wanted, the decision 'must be made by the principal Chiefs only'. ${ }^{48}$ On another occasion he admitted that at the hui at which the Declaration of Independence had been signed 'It was . . . extremely difficult to get the Chiefs to separate themselves from their connexions, and to form themselves into anything like a regular assembly' ${ }^{49}$

Busby proposed other initiatives to distance - in some cases, literally - the principal rangatira from their people, including the construction of separate accommodation for them when they came together for regular meetings of the assembly of confederated chiefs. ${ }^{50}$ His aim to simplify the process of exerting influence and control over the tribes through the establishment of a clearly defined governing hierarchy with definite powers was to be shared by subsequent Crown administrations that were 'looking for a comprehensible and comprehensive body politic with which to negotiate land purchases, ${ }^{51}$ or simply seeking to undermine the 'beastly communism' of Maori society through the establishment of something more or less replicating British class structures. ${ }^{52}$ These measures only began to achieve real results after 1865, especially once the Native Land Court began to undermine communal management of lands. Throughout, the aim had been indirect rule based on elevating the standing of the chiefs within their communities for limited purposes but without providing for anything approaching genuine partnership with the Crown or settler bodies (as seen all too clearly by the exclusion of Maori from parliamentary and provincial assemblies under the New Zealand Constitution Act). By the 1850s these ulterior motives had become all too apparent to many Maori communities, providing the impetus for responses such as revived runanga and the emergence of the Kingitanga. But that is another story..$^{53}$

1 At the risk of pointing out the obvious, the phrase 'manufacturing chiefly consent' is inspired by the well-known work by prominent American activist and linguist Noam Chomsky.

2 See, for example, the various sources quoted to this effect in Harrison M. Wright, New Zealand, 1769-1840: Early Years of Western Contact, Cambridge, Mass., 1959, p.119.

3 Vincent M. O'Malley, 'Runanga and Komiti: Maori Institutions of Self-Government in the Nineteenth Century', PhD thesis, Victoria University of Wellington, 2004, p.9. 


\section{James Busby and the Role of the Rangatira}

4 John Savage, Some Account of New Zealand, London, 1807, p.26.

5 John L. Nicholas, Narrative of a Voyage to New Zealand, 2 vols, London, 1817, vol.1, p.290.

6 Richard A. Cruise, Journal of a Ten Months' Residence in New Zealand, London, 1824, p.209.

7 Samuel Marsden, 'Observations on the Introduction of the Gospel into the South Sea Islands: Being My First Visit to New Zealand in December 1814', in John R. Elder, ed., The Letters and Journals of Samuel Marsden, 1765-1838, Dunedin, 1932, p.118.

8 F.E. Maning, Old New Zealand: A Tale of the Good Old Times, Auckland, 1863, p.37.

9 F.D. Fenton, Report as to Native Affairs in the Waikato District, March 1857, Appendices to the Journals of the House of Representatives, 1860, E-1c, p.11.

10 George Clarke to 'My dear Father and Brother', 31 March 1828, George Clarke Papers, MS-Papers-0250-11, Alexander Turnbull Library (ATL).

11 Samuel Marsden, Journal, 8 October 1823, in Elder (ed.), p.383.

12 Henry Williams, Journal, 6 January 1832, in Lawrence M. Rogers, ed., The Early Journals of Henry Williams, Senior Missionary in New Zealand of the Church Missionary Society, 1826-1840, Christchurch, 1961, p.213.

13 Angela Ballara, Iwi: The Dynamics of Maori Tribal Organisation from c.1769 to c.1945, Wellington, 1998, p.145.

14 Ann R. Parsonson, 'He Whenua te Utu (The Payment will be Land)', PhD thesis, University of Canterbury, 1978, p.39; E.T. Durie, 'Custom Law', unpublished manuscript, 1994, p.39.

15 Parsonson, pp.42-43.

16 Angela Ballara, 'Warfare and Government in Ngapuhi Tribal Society, 1814-1833', MA thesis, University of Auckland, 1973, pp.69-70; James Belich, Making Peoples: A History of the New Zealanders from Polynesian Settlement to the End of the Nineteenth Century, Auckland, 1996, pp.213-16; Hazel Petrie, Chiefs of Industry: Maori Tribal Enterprise in Early Colonial New Zealand, Auckland, 2006, pp.11-12.

17 Wright, pp.155-7; Angela Ballara, Taua: 'Musket Wars', 'Land Wars' or Tikanga? Warfare in Maori Society in the Early Nineteenth Century, Auckland, 2003, pp.425-7; Kathleen Shawcross, 'Maoris of the Bay of Islands, 1769-1840: A Study of Changing Maori Responses to European Contact', MA thesis, University of Auckland, 1967, p.357.

18 Ballara, Taua, pp.423-27.

19 Shawcross, p.357; Raeburn Lange, 'Indigenous Agents of Religious Change in New Zealand, 1830-1860', Journal of Religious History, 24, 3 (2000), pp.289-90.

20 See Anne Salmond, Between Worlds: Early Exchanges Between Maori and Europeans, 1773-1815, Auckland, 1997; Judith Binney, 'Tuki's Universe', New Zealand Journal of History, 38, 2 (2004), pp.215-32.

21 See Eric Ramsden, Busby at Waitangi: H.M.'s Resident at New Zealand, 1833-40, Wellington, 1942; Claudia Orange, The Treaty of Waitangi, Wellington, 1987; Grant Phillipson, 'Bay of Islands Maori and the Crown, 1793-1853', report commissioned by the Crown Forestry Rental Trust, Wellington, 2005, pp.232-54; Donald M. Loveridge, “"The Knot of a Thousand Difficulties": Britain and New Zealand, 1769-1840', report commissioned by the Crown Law Office, Wellington, 2009, pp.42-86; Manuka Arnold Henare, 'The Changing Images of Nineteenth Century Maori Society - From Tribes to Nation', Phd thesis, Victoria University of Wellington, 2003. 


\section{Journal of New Zealand Studies}

22 For the petition, see Warerahi and others to King William, n.d., enclosure to William Yate to Colonial Secretary, 16 November 1831, Great Britain Parliamentary Papers: Colonies New Zealand (GBPP), 1840 [238], p.7.

23 Lord Viscount Goderich to the Chiefs of New Zealand, 14 June 1832, GBPP, 1840 [238], pp.7-8; Orange, p.13.

24 A.D.M. Busby, 'A History of the Busby Family', Edgecliff, NSW, 1994, Vol. Two, p.415, cited in Merata Kawharu, 'Te Tiriti and its Northern Context in the Nineteenth Century', report commissioned by the Crown Forestry Rental Trust, Wellington, 2006, p.87.

25 See Vincent O'Malley, 'English Law and the Maori Response: A Case Study from the Runanga System in Northland, 1861-65', Journal of the Polynesian Society (JPS), 116, 1 (2007), pp.7-34.

26 Richard Bourke to Busby, 13 April 1833, GBPP, 1840 [238], pp.4-6.

27 Busby to Colonial Secretary, 17 May 1833, qMS-0344, ATL.

28 Busby to Colonial Secretary, 13 May 1833, qMS-0345, ATL, cited in Phillipson, p. 240 .

29 Busby to Colonial Secretary, 28 November 1834, Despatches from the British Resident, 1833-1839, qMS-0344, ATL.

30 Busby to Colonial Secretary, 18 January 1836, qMS-0344, ATL; Ormond Wilson, Kororareka and Other Essays, Dunedin, 1990, pp.106-7.

31 Busby to Colonial Secretary, 18 January 1836, qMS-0344, ATL.

32 Ibid.

33 Ibid.

34 Busby to Colonial Secretary, 28 November 1834, qMS-344, ATL.

35 Henry Williams, Journal, 29 October 1834, in Rogers, ed., The Early Journals of Henry Williams, pp.398-9.

36 See Belich, pp.169-70.

37 Busby to Colonial Secretary, 28 November 1834, qMS-0344, ATL.

38 Ibid.

39 Bruce Stirling and Richard Towers, " Not with the Sword But with the Pen:" The Taking of the Northland Old Land Claims: Part 2: Hokianga Scrip Claims, Claim Studies, Appendices and Bibliography', report commissioned by the Crown Forestry Rental Trust, Wellington, 2007, pp.1427-43.

40 Busby to Colonial Secretary, 28 November 1834, qMS-0344, ATL.

41 On the background to these events see Phillipson, pp.232-54; Orange, pp.19-23; Kawharu, pp.72-120.

42 Busby to Colonial Secretary, 31 October 1835, qMS-0344, ATL.

43 James Busby, Remarks Upon a Pamphlet Entitled "The Taranaki Question, By Sir William Martin, D.C.L., Late Chief Justice of New Zealand”, Auckland, 1860, pp.7-8.

44 Busby was not alone, however, in revising his views as to Maori custom the in the wake of the Waitara controversy. Chief Land Purchase Commissioner Donald McLean, for example, having just a few years earlier told a Board of Inquiry into Native Matters that there was 'really no such thing as individual title that is not entangled with the general interest of the tribe' was by 1860 declaring that there were no fixed rules with regards to 


\section{James Busby and the Role of the Rangatira}

customary tenure other than the 'Law of Might'. Evidence of Donald McLean, 17 April 1856, GBPP, 1860 [2719], p.304; Te Karere Maori/Maori Messenger, 31 July 1860.

45 Angela Ballara, 'The Role of Warfare in Maori Society in the Early Contact Period', JPS, 85, 4 (1976), pp.487-506; O’Malley, 'Runanga and Komiti', pp.11-12.

46 William B. Marshall, Personal Narrative of Two Visits to New Zealand, in His Majesty's Ship Alligator, London, 1836, p.108.

47 Ibid., pp.109-10.

48 Busby to Colonial Secretary, 22 March 1834, cited in Loveridge, p.55.

49 Busby to Colonial Secretary, 3 November 1835, qMS-0344, ATL.

50 Ibid.

51 Ballara, Iwi, p.70.

52 O'Malley, 'Runanga and Komiti', p.64.

53 For a brief overview see Vincent O'Malley, 'Reinventing Tribal Mechanisms of Governance: The Emergence of Maori Runanga and Komiti in New Zealand Before 1900', Ethnohistory, 56, 1 (2009), pp.69-90. 
Journal of New Zealand Studies 